International Journal of Medical Sciences

ISSN 1449-1907 www.medsci.org 2006 3(3):92-96

Research paper

(C)2006 Ivyspring International Publisher. All rights reserved

\title{
Serum cystatin C levels to predict serum concentration of digoxin in Japanese patients
}

\author{
Tsutomu Nakamura1, Takeshi loroi', Toshiyuki Sakaeda', Masanori Horinouchi', Nobuhide Hayashi², Kensuke Saito ${ }^{3}$, \\ Mitsuro Kosaka ${ }^{3}$, Noboru Okamura ${ }^{4}$, Keiichi Kadoyama ${ }^{5}$, Shunichi Kumagai ${ }^{3}$ and Katsuhiko Okumura ${ }^{14}$
}

1. Department of Hospital Pharmacy, School of Medicine, Kobe University, 7-5-2 Kusunoki-cho, Chuo-ku, Kobe 650-0017, Japan

2. Clinical Pathology and Immunology, Department of Biomedical Informatics, Kobe University Graduate School of Medicine,

7-5-1 Kusunoki-cho, Chuo-ku, Kobe 650-0017, Japan

3. Dade Behring LIMITED, 1-3-17 Shinkawa, Chuo-ku, Tokyo 104-0033, Japan

4. Department of Clinical Evaluation of Pharmacotherapy, Kobe University Graduate School of Medicine, 1-5-6

Minatojima-minamimachi, Chuo-ku, Kobe 650-0047, Japan

5. Division of Molecular Regenerative Medicine, Department of Biochemistry and Molecular Biology, Osaka University Graduate

School of Medicine, 2-2 Yamadaoka, Suita, Osaka 565-0871, Japan

Corresponding address: Katsuhiko Okumura, Ph.D., Department of Hospital Pharmacy, School of Medicine, Kobe University, Chuo-ku, Kobe 650-0017, Japan. Phone: +81-78-382-6640. FAX: +81-78-382-6676. E-mail: okumurak@med.kobe-u.ac.jp

Received: 2006.03.16; Accepted: 2006.05.05; Published: 2006.05.17

Cystatin $\mathrm{C}(\mathrm{Cys}-\mathrm{C})$ has been recently paid great attention as a better endogenous marker of the glomerular filtration rate than creatinine $(\mathrm{Cr})$. In this study, the usefulness of Cys-C was compared with $\mathrm{Cr}$ in terms of the estimation of the steady-state serum trough concentrations of digoxin in Japanese patients. Forty patients treated with digoxin and 56 healthy elderly subjects were participated in this study. The serum levels of Cys-C and $\mathrm{Cr}$ in the patients were higher than those in the healthy elderly subjects, but the increase of $\mathrm{Cys}-\mathrm{C}$ was more predominant in the patients. Their levels were well-correlated for both of the healthy elderly subjects $(\mathrm{r}=0.691)$ and patients $(\mathrm{r}=0.774)$, but the serum concentrations of digoxin were better correlated with those of the reciprocal values of $\mathrm{Cr}(\mathrm{r}=0.667)$ than those of Cys-C $(\mathrm{r}=0.383)$, presumably due to the fact that digoxin and $\mathrm{Cr}$ were excreted via both glomerular filtration and tubular secretion. Cys-C is useful for the substratification of the patients diagnosed to have normal renal function with $\mathrm{Cr}$ of $<1.3 \mathrm{mg} / \mathrm{dL}$ into those with normal and pseudo-normal renal function, resulting in the corresponding serum concentrations of digoxin.

Key words: Cystatin C, Creatinine, Digoxin, Serum concentration, Heart failure, Renal clearance

\section{Introduction}

Cystatin C (Cys-C) is a non-glycosylated cationic protein of $13.3 \mathrm{kDa}$, belonging to the cystatin superfamily of cysteine protease inhibitors [1,2]. Cys-C is produced by all nucleated cells and is secreted into the blood at a constant rate [1, 2]. Cys-C is freely filtered through the normal glomerular membrane and completely reabsorbed, followed by catabolization by the proximal tubular cells $[1,2]$. The biological fates of Cys-C are favorable as an endogenous marker of the glomerular filtration rate (GFR), similar to creatinine $(\mathrm{Cr})$. The normal range of Cys-C in the serum is from 0.55 (mean-1.96SD) to 0.99 (mean+1.96SD) $\mathrm{mg} / \mathrm{L}$ in Japanese[3], with no inter-ethnic difference [4], and a higher level has been thought to be an index of renal dysfunction. The superiority of Cys-C over $\mathrm{Cr}$ has been debated for the past decade, but in 2002, a meta-analysis of 46 reports concluded that Cys-C is a more useful marker for GFR than $\mathrm{Cr}$ [5]. A multinational expert meeting was held in Germany to summarize the latest findings also in 2002, and it was finally concluded that Cys-C is at least equal if not superior to $\mathrm{Cr}$ as a marker of GFR, and its independence from height, gender, age and muscle mass was highlighted to be advantageous for Cys-C when compared with $\mathrm{Cr}[1]$.
A recently published analysis with an extremely large number of subjects detected the effects of height, gender, age, weight, current cigarette smoking and C-reactive protein on the serum level of Cys-C [6], but it is still thought to be less susceptible to these effects than $\mathrm{Cr}$. For example, the serum level of Cys-C gives almost constant values for the subjects aged of more than 4 months, whereas that of $\mathrm{Cr}$ depends more on age [2]. In addition, recently, it has been demonstrated that Cys-C is more sensitive for moderate renal dysfunction than $\mathrm{Cr}$ [7-9], that is, the patients with a $24 \mathrm{~h}-\mathrm{Cr}$ clearance of $51-70 \mathrm{~mL} / \mathrm{min}$ show a significant increase in the serum level of Cys-C, but no alteration of $\mathrm{Cr}$ was found for such patients [7]. The lower sensitivity of $\mathrm{Cr}$ for moderate renal dysfunction might be due to its tubular secretion [10-12]. Moreover, the possibility of using the serum level of Cys-C to diagnose a certain class of heart diseases, including heart failure, has recently been suggested based on the fact that the serum level of Cys-C, not of $\mathrm{Cr}$, was higher in such patients [13-15]. However, the PRIME study indicated that Cys-C is not a more predictive risk marker of coronary heart disease than CRP or interleukin-6, but could be useful in detecting moderate chronic renal disease [13].

In the present study, the usefulness of Cys- $C$ was compared with $\mathrm{Cr}$ in terms of the estimation of pharmacokinetics of drugs. Here, the analysis was 
performed for the patients treated with a cardiac glycoside, digoxin, since digoxin is mainly eliminated via the kidneys and its individual dose is adequately adjusted based on renal function [16-19]. Due to congestive heart failure and/or supraventricular tachyarrhythmias, the serum level of Cys-C, not of $\mathrm{Cr}$, was expected to be higher, and their association with the serum concentration of digoxin in the steady-state was examined.

\section{Materials and Methods}

\section{Serum samples}

This study was conducted in conformity with Ethical Guidelines for Clinical Studies by the Ministry of Health, Labour and Welfare. Serum samples were collected from 40 patients (25 males and 15 females) visiting Kobe University Hospital from January to July in 2002. These patients were maintained in a stable condition by the once daily oral dosing of digoxin at 0.17 $\pm 0.06(0.06-0.25) \mathrm{mg} /$ day, and the serum samples were subjected to the analysis of the serum concentration of digoxin, as well as the serum levels of Cys-C and Cr. Eight of 40 patients had coadministered with spironolactone $(\mathrm{N}=4)$, quinidine $(\mathrm{N}=2)$ and/or verapamil $(\mathrm{N}=3)$, which may influence the serum concentration of digoxin $[20,21]$ Fifty-six unrelated healthy Japanese elderly subjects ( 37 males and 19 females) were also enrolled to determine the serum levels of Cys-C and $\mathrm{Cr}$. Demographic data for these subjects is represented in Table 1.

Table 1. Demographic data for patients in this study

\begin{tabular}{|c|c|c|c|}
\hline Variable & $\begin{array}{c}\text { Healthy elderly } \\
\text { subjects }\end{array}$ & Patients & $\begin{array}{c}P \\
\text { value }\end{array}$ \\
\hline Number (Male:Female) & $56(37: 19)$ & $40(25: 15)$ & \\
\hline Age (years) & $57.3 \pm 2.0$ & $72.0 \pm 9.0$ & $<0.001$ \\
\hline Weight (kg) & $(55-62)$ & $(50-90)$ & \\
& $(45.6 \pm 9.1$ & $59.0 \pm 11.4$ & 0.234 \\
\hline Height (cm) & $162.3 \pm 7.8$ & $(38.0-85.0)$ & \\
\hline Serum cystatin C (mg/L) & $(146.5-176.0)$ & $(139.3 \pm-8.6$ & $<0.01$ \\
& $0.86 \pm 0.13$ & $1.42 \pm 0.58$ & $<0.001$ \\
\hline $\begin{array}{c}\text { Serum creatinine } \\
\text { (mg/dL) }\end{array}$ & $0.62-1.21)$ & $(0.76-3.07)$ & \\
\hline
\end{tabular}

* The values are the mean $\pm \mathrm{SD}$ with the range in parentheses.

\section{Determination of serum levels of $\mathrm{Cys}-\mathrm{C}, \mathrm{Cr}$ and digoxin}

Serum levels of Cys-C and $\mathrm{Cr}$ were determined by Latex Nephrometry with a Behring Nepherometer II (Dade Behring LIMITED, Liederbach, Germany) and Creatininase F-DAOS assay with a Dimension RxL (Dade Behring LIMITED), respectively. The serum concentrations of digoxin were by Particle Enhanced Turbidimetric Inhibition ImmunoAssay (PETINIA) with a Dimension Xpand-HM (Dade Behring LIMITED). The results were routinely validated to confirm acceptable precision and accuracy.

\section{Statistical analysis}

Values are given as the mean \pm standard deviation (SD). Statistical analysis was performed using SPSS ver. 8.0. The difference of the mean values between healthy elderly subjects and patients was calculated using Welch's non-paired t-test for age, height, weight and serum levels of Cys-C and Cr. Correlations between continuous variables were calculated using Pearson's correlation coefficients in the patients. Multiple comparisons were performed by analysis of variance (ANOVA) followed by Sheffé's test for multiple comparisons provided that the variances of the groups were similar. $P$ values less than 0.05 (two-tailed) were considered to be significant.

\section{Results}

As shown in Table 1 and Fig. 1, serum levels of Cys-C and $\mathrm{Cr}$ were 1.7- and 1.5-fold higher in the patients than those in the healthy elderly subjects, respectively, and the increase was more predominant for Cys-C than $\mathrm{Cr}$. Figure 2 showed the relationships between the serum levels of Cys-C and $\mathrm{Cr}$ in the healthy elderly subjects and patients. The serum levels of Cys- $C$ were well-correlated with those of $\mathrm{Cr}$ both in the healthy elderly subjects (Fig. $2 a, r=0.691$ ) and patients (Fig. $2 b, r=0.774$ ). In the patients with normal renal function (serum level of $\mathrm{Cr}$ of $<1.3 \mathrm{mg} / \mathrm{dL}$ ), a weak correlation was found with $r=0.298$ (open square in Fig. $2 b)$.

Figure 1. Histogram of serum levels of Cys-C and Cr. Fifty-six healthy elderly subjects (open column) and 40 patients treated with digoxin (closed column) were included in this analysis.
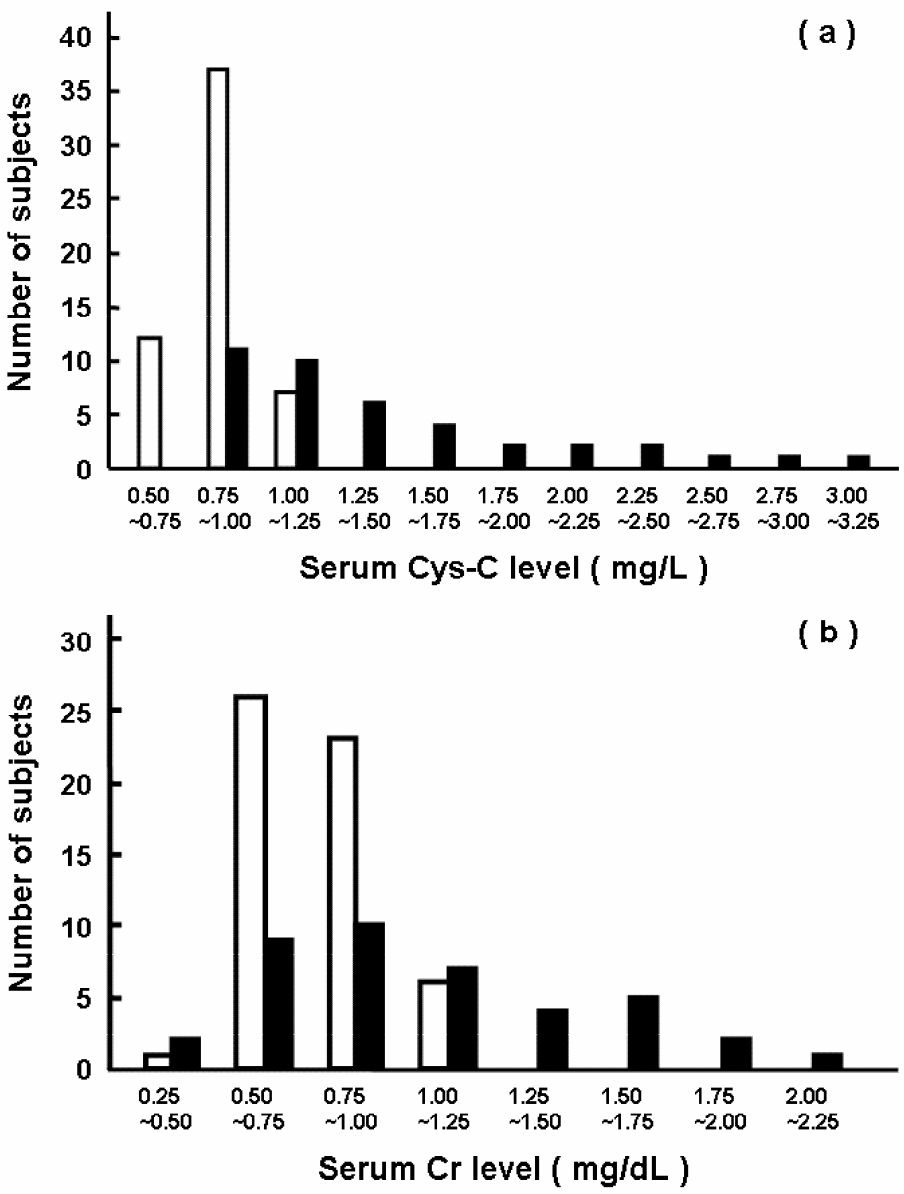
Figure 2. Relationships between serum levels of Cys-C and $\mathrm{Cr}$ in 56 healthy elderly subjects (a) and 40 patients (b). The open circles represent the healthy elderly subjects. The closed and open squares represent the patients with renal function being abnormal (serum level $\mathrm{Cr}, \geq 1.3 \mathrm{mg} / \mathrm{dL}$ ) and normal (serum level of $\mathrm{Cr},<1.3 \mathrm{mg} / \mathrm{dL}$ ). The regression lines were indicated for the healthy elderly subjects (solid in a, $r=0.691$ ), the patients with abnormal renal function (dotted in $\mathrm{b}, \mathrm{r}=0.665$ ) and the patients with normal function (solid in $\mathrm{b}, \mathrm{r}=0.298$ ). The correlation coefficient for the total patients was 0.774 .
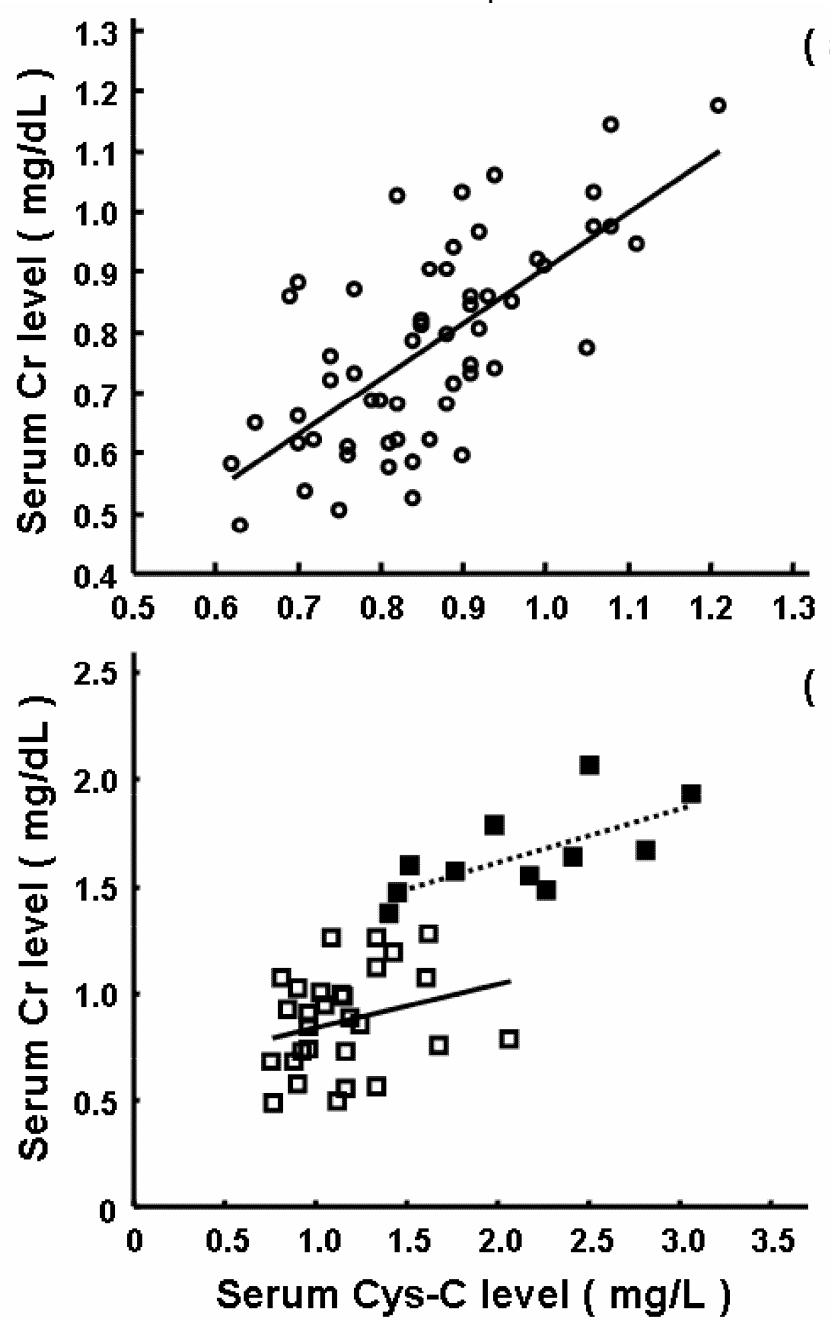

Figure 3 shows the relationship between the serum trough concentrations of digoxin and the reciprocal values of the serum levels of Cys-C (Fig. 3a) and Cr (Fig. $3 b)$. The correlation was better for $\mathrm{Cr}(\mathrm{r}=0.667)$ than Cys-C $(r=0.383)$. Here, the serum level of Cys-C was used for substratification of the patients diagnosed as having normal renal function; i.e., Group I (normal), serum $\mathrm{Cr}$ of $<1.3 \mathrm{mg} / \mathrm{dL}$ and Cys-C of $<1.0 \mathrm{mg} / \mathrm{L}$; Group II (pseudo-normal), serum $\mathrm{Cr}$ of $<1.3 \mathrm{mg} / \mathrm{dL}$, but Cys-C of $\geq 1.0 \mathrm{mg} / \mathrm{L}$; Group III (abnormal), serum Cr of $\geq$ $1.3 \mathrm{mg} / \mathrm{dL}$. All patients belonging to Group III showed serum levels of Cys-C of $1.0 \mathrm{mg} / \mathrm{L}$ or more. The serum concentrations of digoxin were $1.00 \pm 0.32,1.29 \pm 0.36$ and $1.46 \pm 0.41 \mathrm{ng} / \mathrm{mL}$, respectively, with a significant difference between Groups I and III (Fig. 4, $P<0.05$ ). There was no significant difference among the oral dosing amounts of digoxin in Groups I, II and III (0.18 \pm $0.07,0.17 \pm 0.08$ and $0.19 \pm 0.07 \mathrm{mg} /$ day, respectively), and the dose-normalized serum concentration gave the difference between Groups I and III. No significant differences in gender and age were also observed among Groups I, II and III (data not shown).

Figure 3. Relationships between the serum trough concentrations of digoxin and the reciprocal values of serum levels of Cys-C (a) and $\mathrm{Cr}$ (b) in 18 patients treated with digoxin. The correlation coefficients were $\mathrm{r}=0.383$ and 0.667 for Cys-C and $\mathrm{Cr}$, respectively.
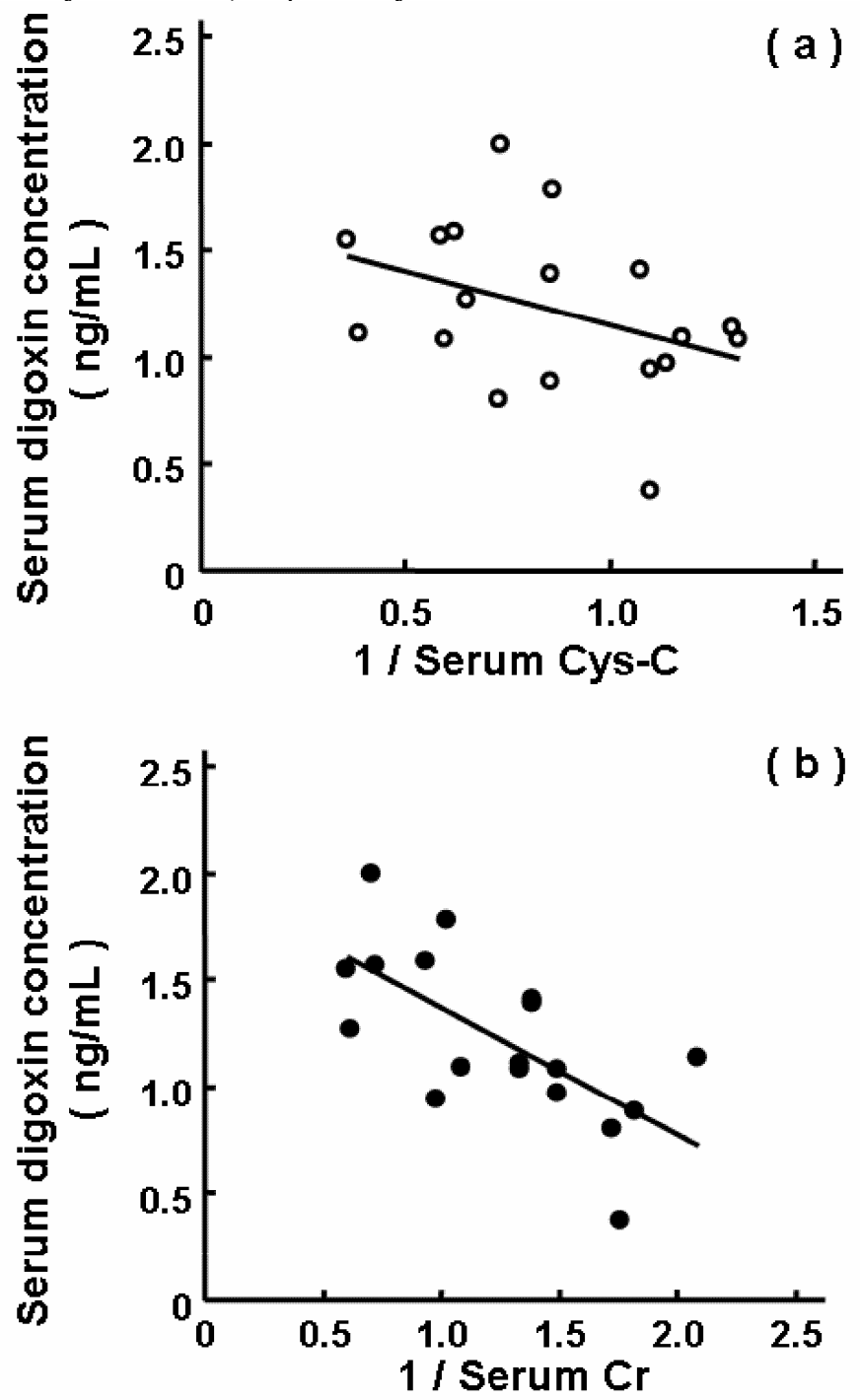
Figure 4. Serum concentration of digoxin for three patient groups substratified based on the serum levels of Cys-C and Cr. Group I (normal), serum $\mathrm{Cr}$ of $<1.3 \mathrm{mg} / \mathrm{dL}$ and Cys-C of $<1.0 \mathrm{mg} / \mathrm{L}$; Group II (pseudo-normal), serum $\mathrm{Cr}$ of $<1.3 \mathrm{mg} / \mathrm{dL}$, but Cys-C of $\geq 1.0 \mathrm{mg} / \mathrm{L}$; Group III (abnormal), serum Cr of $\geq 1.3 \mathrm{mg} / \mathrm{dL}$. All patients belonging to Group III showed serum levels of Cys-C of $1.0 \mathrm{mg} / \mathrm{mL}$ or more. Each bar represents the mean \pm SD. $* \mathrm{P}<0.05$, significantly different from Group I.

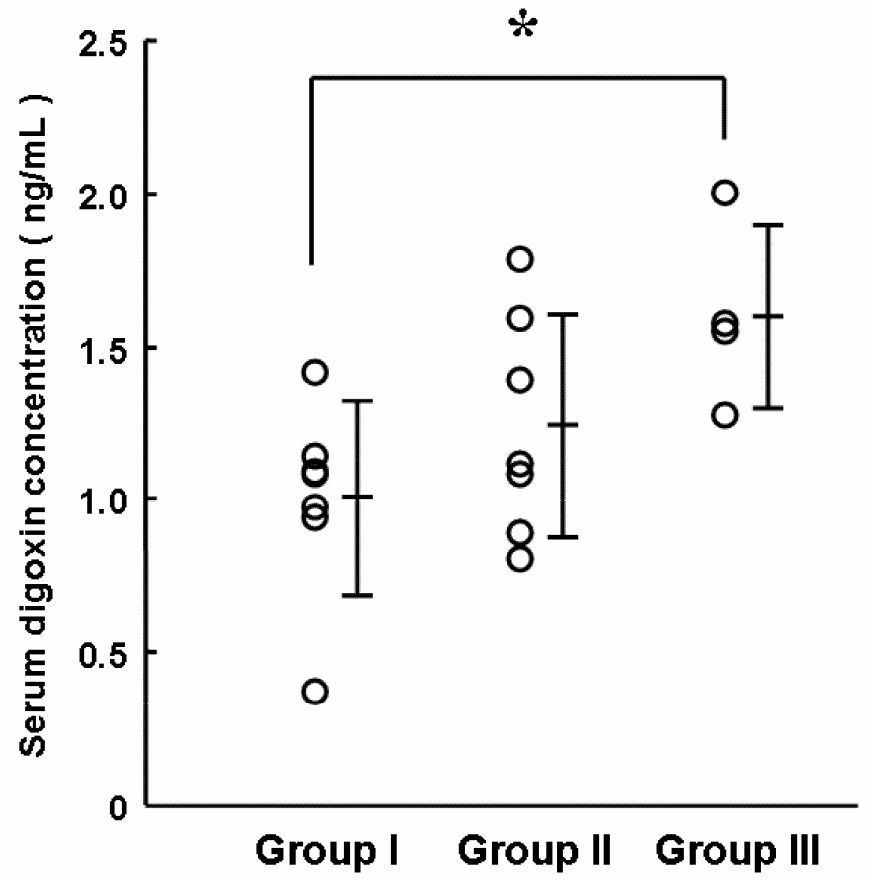

\section{Discussion}

Digoxin shows a narrow therapeutic range, necessitating the routine monitoring of its serum concentration to maximize the therapeutic effects and minimize toxicities [16-19]. Since digoxin is mainly eliminated via the kidneys, the renal function of the patients and its alteration during therapy are important factors to conduct the monitoring and to understand the data on the serum concentration of digoxin [16-19]. The serum level of $\mathrm{Cr}$ has been used to estimate the renal function, and usually the Cockcroft-Gault formula or the Modification of Diet in Renal Disease are usually applied [11, 22-24], however, the effects of gender, age, circadian rhythm and muscle mass on the serum level of $\mathrm{Cr}$, and the lower sensitivity of $\mathrm{Cr}$ for moderate renal dysfunction are often raised as being problematic. Due to the advantages in these areas, Cys-C is expected to be more useful when compared with $\mathrm{Cr}$ in terms of the estimation of digoxin pharmacokinetics.

To date, two reports are published concerning the utility of the serum level of Cys-C to predict the renal clearance of digoxin $[25,26]$. O'Riordan et al. have reported that the serum level of Cys-C is no better than $\mathrm{Cr}$ at predicting digoxin clearance in healthy elderly volunteers, whereas Hallberg and co-workers reported that, in the patients, the serum level of Cys-C correlated better to the serum concentration of digoxin $[25,26]$. In the present study, it was found that the patients showed higher serum levels of Cys-C and $\mathrm{Cr}$, when compared with the healthy elderly subjects (Table 1, Fig. 1). The increase in the serum level was more predominant for Cys-C (Table 1, Fig. 2), being consistent with the reports showing that the serum levels were higher depending on heart diseases [13-15]. Nevertheless, the serum levels of Cys-C were well-correlated with those of $\mathrm{Cr}$ in the healthy elderly subjects (Fig. $2 \mathrm{a}, \mathrm{r}=0.691$ ) and patients (Fig. $2 b, r=0.774$ ). After the stratification of the patients into normal and abnormal renal function with a Cr cut-off value of $1.3 \mathrm{mg} / \mathrm{dL}$, it was indicated that the correlation was weaker, with $\mathrm{r}=0.298$ for the patients with normal renal function, presumably due to the higher sensitivity of Cys-C for moderate renal dysfunction [7-9]. However, as shown in Fig. 3, the serum trough concentration of digoxin was better correlated with the reciprocal values of the serum levels of $\mathrm{Cr}(\mathrm{r}=0.667)$ than Cys-C $(\mathrm{r}=0.383) . \quad \mathrm{Cr}$ was excreted into the urine via glomerular filtration and tubular secretion [10-12], similarly to digoxin [16-19]. Thus, the serum level of $\mathrm{Cr}$ might be useful for the prediction of the serum concentration of drugs excreted via glomerular filtration and tubular secretion, whereas the serum level of Cys-C might be useful for drugs excreted almost exclusively via glomerular filtration. Cys-C might be useful for substratification of the patients diagnosed to have normal renal function with a Cr of $<1.3 \mathrm{mg} / \mathrm{dL}$ into the patients with "true" normal renal function and those with "pseudo" normal renal function, since Cys-C is more sensitive for the detection of moderate renal dysfunction [7-9]. As shown in Fig. 4, the serum concentrations of digoxin depended on the patient substratification. It has been demonstrated that the serum concentration of digoxin at steady state was influenced by age, gender, weight, coadministered drugs, and dosage form, as well as renal function $[20,21]$. Of these factors, oral dosing amounts of digoxin, age and gender were unlikely to be associated with the serum digoxin concentrations among Groups I, II and III. Meanwhile, four of 18 patients had coadministered with spironolactone $(\mathrm{N}=2)$, quinidine $(\mathrm{N}=1)$ or verapamil $(\mathrm{N}=1)$, which may influence the serum concentration of digoxin $[25,26]$. This study was conducted in a moderate population, and future large scale studies are needed to investigate the effect of coadministered medications.

In summary, the usefulness of Cys- $\mathrm{C}$ was compared with $\mathrm{Cr}$ in terms of the estimation of the steady-state serum trough concentrations of digoxin in Japanese patients. The serum levels of Cys-C and $\mathrm{Cr}$ in the patients were higher than those in the healthy elderly subjects, but the increase of Cys-C was more predominant in the patients, due to heart diseases. Their levels were well-correlated for both the healthy elderly subjects and patients, but the serum concentrations of digoxin were better correlated with those of the reciprocal values of $\mathrm{Cr}$ than those of Cys-C, presumably due to the fact that digoxin and $\mathrm{Cr}$ were excreted via both glomerular filtration and tubular secretion. Cys-C is useful for the substratification of the patients diagnosed to have normal renal function with $\mathrm{Cr}$ of less than $1.3 \mathrm{mg} / \mathrm{dL}$ into those with normal and pseudo-normal renal function, resulting in the corresponding serum concentrations of digoxin.

\section{Conflicts of interest}

The authors have declared that no conflict of interest exists. 


\section{References}

1. Filler G, Bokenkamp A, Hofmann W, Le Bricon T, Martenez-Bru C, Grubb A. Cystatin C as a marker of GFR--history, indications, and future research. Clin Biochem. 2005; 38(1):1-8.

2. Newman DJ. Cystatin C. Ann Clin Biochem. 2002; 39:89-104.

3. Ichihara K, Itoh Y, Min WK, et al. Diagnostic and epidemiological implications of regional differences in serum concentrations of proteins observed in six Asian cities. Clin Chem Lab Med. 2004; 42(7):800-809.

4. Uhlmann EJ, Hock KG, Issitt C, Sneeringer MR, Cervelli DR, Gorman RT, Scott MG. Reference intervals for plasma cystatin C in healthy volunteers and renal patients, as measured by the Dade Behring BN II System, and correlation with creatinine. Clin Chem. 2001; 47(11):2031-2033.

5. Dharnidharka VR, Kwon C, Stevens G. Serum cystatin C is superior to serum creatinine as a marker of kidney function: a meta-analysis. Am J Kidney Dis. 2002; 40(2):221-226.

6. Knight EL, Verhave JC, Spiegelman D, Hillege HL, de Zeeuw D, Curhan GC, de Jong PE. Factors influencing serum cystatin $C$ levels other than renal function and the impact on renal function measurement. Kidney Int. 2004; 65(4):1416-1421.

7. Shimizu-Tokiwa A, Kobata M, Io H, Kobayashi N, Shou I, Funabiki K, Fukui M, Horikoshi S, Shirato I, Saito K, Tomino Y. Serum cystatin $\mathrm{C}$ is a more sensitive marker of glomerular function than serum creatinine. Nephron. 2002; 92(1):224-226.

8. Kazama JJ, Kutsuwada K, Ataka K, Maruyama H, Gejyo F. Serum cystatin $C$ reliably detects renal dysfunction in patients with various renal diseases. Nephron. 2002; 91(1):13-20.

9. Heilman RL, Mazur MJ. Cystatin C as a more sensitive indicator of diminished glomerular filtration rate. Liver Transpl. 2005; 11(3):264-266.

10. Shemesh O, Golbetz H, Kriss JP, et al. Limitations of creatinine as a filtration marker in glomerulopathic patients. Kidney Int. 1985; 28(5):830-838.

11. Perrone RD, Madias NE, Levey AS. Serum creatinine as an index of renal function: new insights into old concepts. Clin Chem. 1992; 38(10):1933-1953.

12. Silkensen JR, Kasiske BL. Laboratory assessment of renal disease: clearance, urinalysis, and renal biopsy. In: Brenner BM, ed. Brenner and Rector's the kidney, 7th ed. Philadelphia: Saunders, 2004: 1107-1150.

13. Luc G, Bard JM, Lesueur C, et al. Plasma cystatin-C and development of coronary heart disease: The PRIME Study. Atherosclerosis. 2006; 185(2):375-380.

14. Shlipak MG, Sarnak MJ, Katz R, Fried LF, Seliger SL, Newman AB, Siscovick DS, Stehman-Breen C. Cystatin $C$ and the risk of death and cardiovascular events among elderly persons. N Engl J Med. 2005; 352(20):2049-2060.

15. Sarnak MJ, Katz R, Stehman-Breen CO, et al. Cystatin C concentration as a risk factor for heart failure in older adults. Ann Intern Med. 2005; 142(7):497-505.

16. Mooradian AD. Digitalis. An update of clinical pharmacokinetics, therapeutic monitoring techniques and treatment recommendations. Clin Pharmacokinet. 1988; 15(3):165-179.

17. Reuning RH, Geraets DR. Digoxin. In: Evans WE, Schentag JJ, Jusko WJ, eds. Applied pharmacokinetics, principles of therapeutic drug monitoring, 2nd ed. Spokane: Applied Therapeutics, 1986: 570-623.

18. [No authors listed]. Rationale, design, implementation, and baseline characteristics of patients in the DIG Trial: a large, simple, long-term trial to evaluate the effect of digitalis on mortality in heart failure. Control Clin Trials. 1996; 17(1):77-97.

19. Rathore SS, Curtis JP, Wang Y, Bristow MR, Krumholz HM. Association of serum digoxin concentration and outcomes in patients with heart failure. JAMA. 2003; 289(7):871-878.

20. Hori R, Miyazaki K, Mizugaki M, Ogata H, Goto M, Ichimura F, Yasuhara M, Tanigawara Y, Hashimoto Y, Koue T, Mimaki T, Tanaka K, Okumura K, Gomita H, Higuchi S. Estimation of population pharmacokinetic parameters in the Japanese. I. Digoxin. Jpn J Ther Drug Monit. 1994; 19(3):7-17.
21. Nakamura T, Kakumoto M, Yamashita K, Takara K, Tanigawara Y, Sakaeda T, Okumura K. Factors influencing the prediction of steady state concentrations of digoxin. Biol Pharm Bull. 2001; 24(4):403-408.

22. Cockcroft DW, Gault MH. Prediction of creatinine clearance from serum creatinine. Nephron. 1976; 16(1):31-41.

23. Levey AS, Bosch JP, Lewis JB, Greene T, Rogers N, Roth D. A more accurate method to estimate glomerular filtration rate from serum creatinine: a new prediction equation. Modification of Diet in Renal Disease Study Group. Ann Intern Med. 1999; 130(6):461-470.

24. Rahn KH, Heidenreich S, Brückner D. How to assess glomerular function and damage in humans. J Hypertens. 1999; 17(3):309-317.

25. O'Riordan S, Ouldred E, Brice S, Jackson SH, Swift CG. Serum cystatin $\mathrm{C}$ is not a better marker of creatinine or digoxin clearance than serum creatinine. Br J Clin Pharmacol. 2002; 53(4):398-402.

26. Hallberg P, Melhus H, Hansson LO, Larsson A. Cystatin C vs creatinine as markers of renal function in patients on digoxin treatment. Ups J Med Sci. 2004; 109(3):247-253. 